\section{OP-257High-risk 局所前立腺癌の治療成績}

\section{古賀総合病院泌尿器科}

南口 尚紀, 福井 嵩之, 平山きふ

【目的】High-risk 局所前立腺癌患者に対する根治的治療と して前立腺全摘および外照射療法後の PSA 再発までの期 間につき比較検討を行った。【方法】 D'Amico らのリスク 分類に基づき、PSA > 20ng/ml、Gleason score8 以上のい ずれかを満たす局所前立腺癌症例をハイリスク前立腺癌と 分類した。2001 年より 2008 年までに当院で施行した前立 腺全摘除術 181 例中 50 例、外照射療法 93 例中 46 例を対 象とした。全摘群、外照射群につき単独症例、Neoadjvant 療法に分けての検討を行った。【成績】年齢は全摘群 51 〜 74 歳（平均年齢 66.3 歳）、外照射群 $53 \sim 76$ 歳（平均年齢 69.2 歳)、診断值 PSA は全摘群 $4.75 \sim 87.27 \mathrm{ng} / \mathrm{ml}$ (平均 $25.01 \mathrm{ng} / \mathrm{ml}$ )、外照射群 $4.10 \sim 257.40 \mathrm{ng} / \mathrm{ml}$ (平均 $45.2 \mathrm{ng}$ / $\mathrm{ml}$ ) であった。臨床診断は全摘群 T2 以下 25 例、T3a25 例、 外照射群 T2 以下 14 例、T3a32 例であった。生化学的再 発を全摘群 18 例、外照射群 $\mathrm{T} 2$ 以下 13 例に見られた。全 摘群では手術単独群 18 例（再発 4 例 22.2\%)、Neoadjvant 療法群 32 例（再発 14 例 43.8\%）で、外照射群では単独群 7 例（再発 3 例 42.9\%)、内分泌療法併用群 39 例（再発 10 例 25.6\%) であった。全摘群ではPSA が低い（<10）も のが 16 例と多く含まれており、手術単独でも再発頻度が 低かった $(3 / 10$ 例)。【結論】ハイリスクに分類された前 立腺癌患者の全摘・外照射療法はPSA 再発率は高いが、 根治性も充分あると考えられた。

\section{OP-258}

生検 Gleason score 8 以上の前立腺癌に 対する前立腺全摘術の治療成績

\section{癌研究会有明病院泌尿器科 ${ }^{1)}$, 癌研究会病理部 ${ }^{2)}$}

沼尾 昇 ${ }^{1)}$, 山本 真也 ${ }^{11}$, 安田 庸輔1), 助川 玄1) 伊藤 将也 ${ }^{1)}$, 久保 雄一 ${ }^{11}$, 吉川 慎一 ${ }^{17}$, 湯浅 健 $^{17}$, 浦上 慎司 ${ }^{12}$, 米瀬 淳二 ${ }^{1}$, 石川 雄一 ${ }^{2}$, 福井 嚴 ${ }^{12}$ 【目的】生検 GS 8 以上の前立腺癌に対する、前立腺全摘 術（RP）の治療成績を明らかにすること。【対象と方法】 1994-2008 年まで施行した RP 症例 1112 例のうち、生検 GS 8 以上、術後 1 年以上経過観察できた 236 例。術式は順 行性で、神経非温存症例では膀胱頚部、神経血管束を広沉 に摘除し、デノビエ筋膜は原則として前立腺尖部から精囊 先端部まで合併切除している。1）全摘標本に扔ける病理 学的所見の検討、2) PSA 非再発生存率 (BFS)、局所無再 発生存率 (LFS)、非遠隔転移生存率 (DFS)、疾患特異的 生存率 (CSS)、全生存率 (OS) の解析 3) PSA 再発、遠 隔転移の予測因子の検討、を行った。【結果】 PSA 中央値 $13 \mathrm{ng} / \mathrm{mL}$ 。観察期間中央值 48 力月。臨床病期は T1/T2/ $\mathrm{T} 3 \mathrm{a} / \mathrm{T} 3 \mathrm{~b} / \mathrm{N} 1$ が 43/109/73/11/0 例。生検 GS は 8/9/10 が 94/137/5 例。121 例に術前内分泌療法 (NHT)、12 例に術 後内分泌療法 (AHT) が行われた。NHT - / +群でpT3 以上が 44/46\%、断端陽性率 37/16\%で、断端陽性症例の約 半数が尖部単独であった。AHT - 群の BFS は術後 3/5/7 年で 76/66/60\%で再発後の初期治療は内分泌 / 放射線 / 経 過観察が 60/23/17\%であった。全症例の LFS/DFS/CSS/

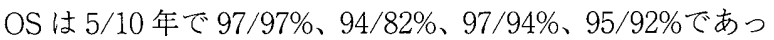
た。PSA 再発にはPSA、臨床病期、GSが、遠隔転移では PSA が多変量解析にて有意な予測因子であった。【結語】 GS8 以上の前立腺癌に RP は良好な長期成續を示した。

\section{OP-259 血清 PSA 值 $20 \mathrm{ng} / \mathrm{ml}$ 以上の前立腺癌 に対する血管蒦処理先行広範順行性前立 腺全摘除術の治療成績}

\author{
（財）癌研究会有明病院泌尿器科 \\ 浦上 慎司, 米瀬 淳二, 山本 真也, 吉川 慎一, \\ 沼尾 昇, 久保 雄一, 伊藤 将也, 助川 玄, \\ 安田庸輔, 福井 嚴
}

【目的】我々は局所進行前立腺癌に対して前立腺周囲を広 範に切除する血管荎処理先行順行性前立腺全摘除術（広範 前立腺全摘）を施行し、その根治の可能性を追求してき た。今回 PSA 值 $20 \mathrm{ng} / \mathrm{ml}$ 以上の前立腺癌に対する広範前 立腺全摘の治療成績について検討する。【対象および方法】 1994 年 -2008 年に手術を施行したiPSA20 以上の前立腺癌 240 例を後乃向きに検討した。年齢は 47-80 歳（中央值： 68)。iPSA は20.1-660 ng/ml（中央值：33.0）。前立腺生検 の Gleason score はฏ6、7、8-10 がそれぞれ 35 例、123例、 79 例。cT1-2、cT3-4 がそれぞれ 123 例、117例。ネオアジュ バントホルモン療法は 160 例 (66.7\%) に施行した。【結果】 全摘標本の病理所見は pT0 : 2 例、pT2:107 例、pT3a： 65 例、pT3b：60 例、pT4：2 例で pN1 は 23 例 (9.6\%) に 認めた。切除断端陽性が 79 例 (32.9\%) に認められた。即 時アジュバントホルモン療法は希望した14例に施行した。 観察期間中央值は58 ケ月。PSA 再発までの期間は中央值 49 ヶ月で、 5 年· 10 年非 PSA 再発率は $48.9 \% 、 46.8 \%$ あった。 また 5 年・10 年全生存率は $97.6 \% 、 91.6 \%$ あった。治療 前の各種パラメーターでは iPSA 值高值と臨床病期が有意 なPSA 再発の危険因子となった。結論】iPSA20以上であっ ても、約半数に広範前立腺全摘により根治が期待できる。 今後治癒率をさらに向上させる対策を考察したい。

\section{OP-260} 当院における根治的前立腺全摘術後 pT3
もしくは切除断端陽性例の臨床的検討

\section{名古屋記念病院泌尿器科}

大前 憲史, 内藤 和彦, 深谷 孝介, 藤田 民夫 【目的】当院では根治的前立腺全摘術後 pT3 ししくは切除 断端陽性例に対し積極的にアジュバント療法として内分泌 療法や放射線療法を施行してきた。それらを臨床的に検討 し今後の同様の症例に対する当科としての方針を検討し た。【対象と方法】対象は 1999 年 1 月から 2008 年 12 月ま でに当院で前立腺癌に対し根治的前立腺全摘術を施行し病 理学的検索にてpT3もしくは切除断端陽性であった 36 例。 年齢、PSA 值、術前臨床病期等についての検討に加え、 術後アジュバント療法を行わずに経過観察した群（WW 群)、アジュバント療法として内分泌療法単独群 (ADT 群)、放射線潦法単独群 (RT 群)、両者の併用群 (ADT+RT 群）それぞれにつきPSA 再発や生存率に関して検討した。 【結果】年齢は平均 68.1（55～75）、PSA 值は平均 15.4、 中央值 $10.7(4.656 \sim 71.4)$ 、術前臨床病期は T2a が 8 例、 T2bが 6 例、T2cが 17 例、T3a が 4 例、T3bが 1 例であった。 また WW 群 8 例、ADT 群 12 例、RT 群 5 例、ADT+RT 群 10 例でそれぞれPSA 再発を認めたのは 2 例、1 例、 3 例、0 例であった。いずれも内分泌療法の追加や再開で PSAのコントロールは良好で死亡例は認めなかった。【考 察】今回の検討は症例数が少なく観察期間も短かったため アジュバント療法の有無やアジュバント療法各群で PSA 再発や生存率に関して有意な差は認めなかった。 